\title{
Patronage, Ideology and Manipulation: The Translation of Ao-men Hsin-wen-chih During the First Opium War
}

\author{
WANG Hai ${ }^{1}$, XIAO Li ${ }^{1}$ \\ ${ }^{1}$ Guangdong University of Foreign Studies, Guangzhou, China \\ 3038396192@qq.com
}

\begin{abstract}
During the special historical period of July 1839 to November 1840, Lin Tse-hsu and his translator team selected and translated some articles from foreign newspapers such as The Canton Press, The Canton Register, The Canton Miscellany and The Chinese Repository into Chinese, which were collected intoAo-men Hsin-wen-chih(Macao News). This article explores the manipulation of patronage and ideology over the translation of Ao-men Hsin-wenchih. As the undifferentiated patron of Ao-men Hsin-wen-chih, Lin Tse-hsu was involved in translator selection, source text selection, adding target-text annotation and he even determined and interacted with the target readers. It is also revealed that under the manipulation of patronage and ideology, the translators rewrote thetranslation by adopting such strategies as edited translation and adaptation, foreignization and domestication, uglification and dwarfing.
\end{abstract}

Keywords : Ao-men Hsin-wen-chih; ideology; manipulation

\section{Introduction}

According to Lefevere (1992a: vii), translation is produced on the basis of an original text with the intention of adapting the original to a certain ideology or poetics of a different audience, and it is an activity performed under constraints of patronage, poetics and ideology initiated by the target systems, as such it is an act of rewriting of an original text to conform to certain purposes instituted by the receiving system.

Andre Lefevereholds that literature is a character system nurtured in certain social background under poetics, it results from social ideology, so it is ideology and poetics that dictates whole translation. To put it simply, academics, reviewers, teachers and translators themselves are "professionals" within the literary system, they decide on the poetics and at times influence the ideology of the translated text; while "persons or institutions" that can further or hinder writing and translation stand outside the literary system, they are what Lefevere called "patronage" or the effect of ideology (Andre Lefevere, 1992:10-16 ).

Ranging from translation to literary writing, the conflict between poetics and ideology exists in every civilization and cultural backgrounds at all times and in all over the world. "Patrons are mainly ideologically focused" (Andre Lefevere, 1992:14-15). External motivations (patrons and their ideology) dictate the work of internal motivations (academics and their poetics), that means patrons representing the dominant ideology of one culture or society give a set of decisive ideological indicators, which will be the yardstick to measure the poetic activity of academics and translators.In a word, translation is an activity where translators manipulate and rewrite under the influence of dominant ideology and poetics of that country.

On March 10th, 1839, Lin Tse-hsu came to Canton as an imperial commissioner to ban the opium trade, To study British conditions and tackle with British counterparts accordingly (William C. Hunter, 1855: 24), Lin and Wei, in their residence, secretly organized translators to translate relevant foreign reports in the English periodicals. Amid great tension between China 
and foreign countries in 1830s, Lin Tse-hsu recruited four translators to collect information and carry out translation activity on Ao-men Hsin-wen-chih in Yue Hua College of Guangzhou. ( $\mathrm{Su}$ Jing, 2015:116). Since July 1839, translators sponsored by Lin Tse-hsu selected and translated reports and comments from foreign periodicals in Canton and Nanyang, including The Canton Register (1827-1844), The Canton Press (1835-1844), The Canton Miscellany (1831) and The Chinese Repository(1832-1851), also some from foreign periodicals published in Singapore, Bombay, Calcutta, London and Sydney collected from Macau, which mainly about opium trade, war, fleet and weapons. All translated versions were collectively called Ao-men Hsin-wen-chih

(Macao News) later. Presently, the total 6 volumes are collected in Nanjing Library, the revised copy book and condensed versions are employed by scholars in their study (Su Jing, 2015: 100).

Domestically and internationally, the subject of translation often understated when studying or discussing the Opium War (Wang Hongzhi, 2011:84).Few works focus on the translation activity led by Lin Tse-hsu. Translators during the First Opium War: Translators in China (Part One) by Wang Hongzhi and Versions, Master Copy, Translators and Translation of Ao-men Hsin-wen-chih by Su Jing have systematically discussed the translation activity of Ao-men Hsin-wen-chih. Wang Hai and Chen Caiyun (2013:91-98) analyzedsome of the translation strategies and skills applied in Ao-men Hsin-wen-chih.

Drawing on the concepts of the rewriting theory of Andre Lefevere, this article aims to explore the rewriting and manipulation of Lin Tse-hsuand his translation team over the translation ofAo-men Hsin-wen-chih.

\section{Review of Literature}

\subsection{Patronage's Direct Manipulation Over the Translation activity}

\section{A. Patron-translator Relationship}

Patronage basically consists of three elements: the ideological, the economic component and the status components, which can be seen to interact in various combinations. Patronage is undifferentiated when its three components are all dispensed by one and the same patron (Lefevere, 1992:16-17), as is the case of the translation of Ao-men Hsin-wen-chih.

Lin Tse-hsu's undifferentiated patronage almost turned the translators into his substitutes. The real translators' names were omitted. These translators were inferior in Qing government and the society then, and as they were secretly organized by Lin and their activity was certainly undercover since the Chinese primary sources then didn't give their names.

An article titled Crisis in the Opium Traffic gave brief introduction of Lin's translators (The Chinese Repository, 1839:77):

Lin's team consistsof four Chinese translators, they have made some progress in the English tongue. The first is a young man, educated in Penang Island and Malacca, and for several years employed by the Qing government at Peking. The second is an old man, educated at Serampore, India. The third is a young man who was once at the school at Cornwall, Connecticut, U.S.A.The fourth is a young lad, educated in China, who is able to read and translate papers on common subjects, with much ease, correctness and facility.

According to the records by the American Board of Commissioners for Foreign Missionsand the London Missionary Society, these four Chinese translators are ShaouTih (Yuan Te-hui), Atih (Liang Jinde), Âmân and William Botelho (Liaon Ah see)（Su Jing, 2015: 
34-58 ).Lin hiredthose translators, which gives a means to make a living, who thus devoting themselves to translation. "Lin Tse-hsu"lured"“the most diligent man (Liaon Ah see) among the translators(The Chinese Repository,1841:565)". When working in Canton, Lin asked him (Liaon Ah see) to be responsible for translation of all "foreign papers and books. He was well treated and offered generous monthly pay."(Britton, 1966:32).

As for the social status, the four translators sponsored by Lin Tse-hsu were basically underclass who had earned their lives at grassroots. Atih had been an engraver at London Missionary Society, Aman had studied at an Indian church school for more than a decade and translated the Bible(Fang Hanqi1996:454). Alum had taught Chinese staffs English at a foreign firm. As they started to work at the office of Lin Tse-hsu, they had been elevated to be government officials.

\section{B. Selection of Source Texts}

Translation is not simply an act of faithful reproduction, but a deliberate and conscious act of section, assemblage, structuration, and fabrication (Tymoczko \& Gentzler, 1999). In the case of Ao-men Hsin-wen-chih, the selection of source text was influenced and determined by the translation purpose and the ideology of Lin.

To begin with, Lin was involved in the selection of the source newspapers. Among the 177 articles in Ao-men Hsin-wen-chih, 141 were selected from The Canton Press, accounting for $80 \%$; 21 were from The Canton Register, accounting for 12\%, withonly 15 fromThe Singapore Free Press. Undoubtedly,The Canton Press is the main source newspaper of those articles. (Su Jing,2015:29).Different from The Canton Registerrun by the British,the Canton Register sometimes criticized British businessmen, the East India Company and even the British government. Lin probably knew about this through the translators and thus believed that The Canton Press was more open and could be a better source for the foreign affairs. In addition, The Canton Press also held a milder attitude toward Lin Tse-hsuand expressed the viewpoint that opium banning was quite reasonable and justified for more than one time. Instead of criticizing Lin as The Canton Register always did, it gave Lin both criticism and praise. Sometimes there were even more praise than criticism. By contrast, many articles in The Canton Registerhad criticism over. Lin Tse-hsu.

Moreover, Lin also manipulated the selection of the subjects of the source texts. "Lin and his assistants hadn't been much exposed to English, they couldn't pinpoint the translation content, therefore, they may give the macro range involving reports on China, activities of foreigners and their home country or trade in tea and opium, then translators selected and translated therefrom, or pinpointed the content for translation from the translated papers. The contents selected and translated were inevitably subject to Lin's review (Su Jing, 2015:135)

Articles in Ao-men Hsin-wen-chih were polished and edited into five series of Ao-men Monthly Report, including conditions of China and other countries, tea and military strategy, among others, which later were integrated into Hai-kuoT'u-chih by Wei Yuan and signed with Lin Tse-hsu as the translator. Those are also the five main topics of the articles of Ao-men Hsinwen-chih. All of those topics are closely related to Lin's intention in initiating Ao-men Hsinwen-chih.To begin with, banning onopium trade is one of the most important topics. As an imperial commissioner, Lin Tse-hsu' s top priority was to ban opium trade, that's why "quite a lot were about opium trade.'(The Chinese Repository, 1839 (2):77).

Moreover, by organizing the translation of Ao-men Hsin-wen-chih,Lin Tse-hsu aimed to 
learn more about foreign affairs, thus worked out countering strategies accordingly. With the mission to ban opium trade and combat UK, Lin Tse-hsu was eager to know foreign affairs, That's why many translations on foreign conditions can be found in Ao-men Hsin-wen-chih. (Su Jing, 2015:136).

Meanwhile, as a pillar of China's export and government revenue, tea held great importance to foreigners. That's why many selective translations about tea can be found in $\mathrm{Ao}$ men Hsin-wen-chih. The selective translation about military strategy resulted from the first Sino-UK War, when Lin Tse-hsu recognized foreign power's ambition and strong military force relative to Qing authority's weak strength and weapons. "Generally, the whole Chinese nation had no reaction to the first Sino-UK War from 1839 to 1842 , only a few far-sighted officials appeared to see what British fleet may bring about. Lin Tse-hsu came to Canton in 1839 as an imperial commissioner, regulating the actions of foreigners."(Britton, 1966:30). These motivated Lin's translators to select and translate foreign information about military use and submitted them to the court.

\section{Target-Text Annotation}

As the patron and also one of the main target readers ofAo-men Hsin-wen-chih, Lin added some annotations or notes to the target text. About 11 articles contain annotations, most of which are believed to be written by Lin (Feng Zuyi, 2010:126). In those annotations, Lin made comments and expressed his viewpoints or even criticism toward the issues mentioned in the articles.

In some annotations, Lin pointed out the mistakes in the articles. For example, in an article dated April 25, 1840, there were discussions on the soldiers' salary and provisions of the Qing dynasty. Lin commented: "The amount of the salary and provisions in this article is not accurate!". In an article dated May, 16, there were comparisons of the tax income between China, Russia, Britain and France. Lin's comments show his doubts about the tax income: "All the data about the tax income in China is not correct! I cannot help but wondering the source of the information."

Apart from showing his criticism, Lin even offered suggested measures to the problems mentioned in the article. For example, in an article dated December 3, 1839 discussing the opium monopoly in India, the author believed that opium monopoly might lead to smuggling. Lin commented: "This is very much alike the situation of saltworks in China, where some measures should be adopted against the smuggling".An article dated Aril 20, 1840 talked about Qing government intending to demolish the houses in the suburban areas of Guangzhou in order to protect the downtown area from the British invasion, but there were too many residents in the suburban areas. Lin's annotations read as follows: "Why not build walls around the inner city?", which actually offered suggestions to protect Guangzhou residents against the British invasion.

Those commentary annotations, as part of the paratexts of the translated texts, reflect Lin's direct manipulation of the translated texts. Although they only accounted for a small portion, they real/show the ideas and viewpoints of Lin and they might also influence the understanding of target texts by other readers,

\section{Patron and the Target Readership}

Though Ao-men Hsin-wen-chih is called the earliest translated newspaper in China, it was not published. The translator team sponsored by Lin Tse-hsu was an individual agency, 
where translators generally translated English publications into Chinese as a reference for Lin or submitted to the government, and they didn't attempt to publish their works (The Chinese Repository, 1839:77). Therefore, its target readers, rather than being the general public, was quite limited within a small group of people, including Lin, some of the government officials and Emperor Daoguang.

The limited readership was determined by the social environment and conditions. Before the First Opium War, Qing government had closed its door to the outside world with a posture of "celestial power", and foreign culture was dismissed. "Chinese culture had been much developed, where history was prioritized over the present and future, thereby, Chinese scholars tended to review the past. Chinese people paid no attention beyond their surroundings, not to mention foreign countries."(Britton,1966:2).During that period, officials including Qi Shan criticized the translation activity sponsored by Lin Tse-hsu, whose attempt to learn about foreign countries was also stigmatized. For quite a long time, foreign languages and foreign newspapers had been dismissed_by Chinese officials. Under this circumstance, it's not hard to understand the reason why Lin did not attempt to get the translation published. Therefore, instead of publishing the translations, as the patron and also the target reader, Lin Tse-hsu chose the other limited target readers by himself. He sent the paper copy of the translated news to several government officials who he believed were willing to know the foreign affairs. Those officials include governor of Guangdong and Guangxi, provincial governor of Guangdong and custom supervisor as well as several officials in the military troops. Besides, In March 1840, Lin also submitted six letters translated from the newspaper to Emperor Daoguang ( Lin Tsehsu, 1840:84).

Moreover, Lin also highlighted his purpose and initiative in organizing and sponsoring the translation activity with those target readers he chose. In one of his memorials to Emperor Daoguang, he also expressed reason for the translation: "Since it is urgent time to precaution against the barbarians, it is necessary to search for the affairs of the barbarians. Only by knowing their situations can we make the strategies to contain them. "(Lin Tse-hsu,1840).

\section{Discussion}

\subsection{The Ideological Manipulation over the Translation Strategies}

Lin Tse-hsuprobed into the foreign affairs via translation of foreign newspaper and books., an ideology which is different from other officials of the Qing dynasty, since most of the officials and Emperor Daoguang were not interested in the foreign affairs at all. However, as a feudal official, Lin regarded China as the "Celestial Empire" and he still had cultural arrogance and the sense of superiority. For Lin, translation is an important way to learn more about the foreign affairs so as to contain the foreign countries. Therefore, His ideology,to some degree, still caters to the mainstream ideology of the Qing Dynasty. In the following part, the essay will explore how the translation strategies were manipulated and rewrote under the influence of the ideology of Lin.

\section{A. Edited Translation and Adaptation}

A comparative textual analysis of the original and the target version reveals the fact that the translators of Ao-men Hsin-wen-chihadopted such strategies as edited translating and 
adaptation. Such translation techniques as addition, deletion, editing and even adaptation are very common in more than half of the 177 translated articles.

For example, in an article translated from Canton press, the authordiscussed the possibility of sending missionary doctors to China and the benefits. In the original text, there were obviously two themes: missionary and medicine. However, in the target text, the translator completely deleted information about the religion and only translated those parts about medicine. Apart from that, at the beginning of the article, translator also added one paragraph by imitating the tone of the foreigners.“中国之人民, 平常尽皆恨恶我等, 不与 我等往来, 况又有官府之严禁, 致我等虽用尽法子, 欲解除中国人恨恶我等之心, 惟 总不能得之。”(Chinese people have always had a hatred toward us and refused to communicate with us. Besides, with the prohibition from Chinese government, although we have done our utmost to dissolve Chinese people's hatred and resentfulness toward us, we failed at last.)

In addition, deletion or omission of certain sentences can also be seen. For example, in an articleof Canton Press, there were some negative commentary remarks on Chinese Emperor:"Emperor is so weak that a few handful of "despised foreigners can horn him in--can establish....This is the real cause of the exclusive policy of the Chinese." (The Canton Press, 1839-10-12.) In translating this paragraph, offensive remarks to the emperor such as "Emperor is so weak that a few handful of despised foreigners can horn him in..." was completely omitted in the translation.

Besides, rewriting and adaptations can be found in some translations. For example, in an article describing the Chuenpeewar. In the end of the article, the author wrote like this: "It is difficult to foresee how this action may affect the disposition of the Chinese towards and arrangement with the English ; we almost believe that they will become more tractable."The original version adopted the word "tractable", indicating that the English believes that Chinese will become more easily manipulated or controlled after the war. However, the translation of this sentence was adapted into the following:“现在已有此等情节，再难望中国好待我也”, which means that the British believe that the Chinese will not treat them well after the war. The meaning of the translated version was completely distorted by the translators.

\subsection{Domestication and Foreignization}

A comparison of the source text and the target text of Ao-men Hsin-wen-chih reveals that domesticationwas the main translation strategies although foreignization was also used. First, in terms of genre, the source text varies from news, comments,commercials etc., each of which has its own writing style, stand and purpose. However, instead of keeping the original genre, the translators selected parts of news or commentary articles and rearranged them into "articles" without titles (Su Jing, 2015:138)Therefore, though the collection of which was titled Macao News. the target texts are not technically news anymore. In terms of genre, Ao-men Hsin-wenchih(Macao News) was more like collections of memorialsintended to submit to Lin and the other officials.

In a lexical level, both domestication and foreignization were employedto translate proper names.For example, “population” was domesticated into“户口”(hu kou, number of households and total population ), and "priest” was rendered into “和尚”( he shang, monk). 
“House of Commons” was transliterated into “甘文好司”; “House of Lord” became “律好 司”, etc. Moreover, the translators even adopted both domestication and foreignization by offering two target versions for the same word or phrase. For example, both western calendar and Chinese lunar calendar were employed to render the same English chronology. "1830" was translated into “一千八百三十年道光十年庚寅” (1830, the $10^{\text {th }}$ regal year of Emperor daoguang, the year of Gengyan ${ }^{\square}$ ). The same strategy can also be found in the translation of foreign currency. For example, the currency unit"pound"was rendered into “棒( bang)", and the translator also provided the amount of money in Chinese currency. So, "200 pounds" was rendered into“二百棒一千圆( 200 pounds, 1000 Chinese yuan)”. By doing so, the translators not only managed to introduce the "foreign affairs" by keeping the original information in a foreignized manner, but also catered to the reading habit of Lin Tse-hsu and the other government officials.

\subsection{Uglificationand Dwarfing}

Before the First Opium War, Chinese appraised the west countries with the eyes of the CentralState, denying the new civilization in Europe, severely distorting the western image.In the eyes of Chinese, the westerners are barbarians and therefore they were called “蛮夷”(Man Yi $)^{\square}$. The Yi image or barbarian image imagination of the western other can be seen in the translations ofAo-men Hsin-wen-chih.

To begin with, Chinese character"夷（Yi）"was frequently used in the translated texts to refer to the foreigners. "Foreigner" was translated into “夷人” (Yi Ren , barbarians); “the English “was translated into “英夷” (Ying Yi, British barbarians), the foreign factories was rendered into “夷馆”(Yi Guan, the factories of the barbarians), which implied contempt and hatred toward the foreigners (Li Changyin, 2008:144).

Besides, Chinese characters containing derogatory meaning were used in the transliteration of the names of foreigners. Such derogatory Chinese characters as “渣”( $z h a$, bad ) was used to translate the foreign names.For example,“ George I" was“渣治第一”in thetarget text. Besides, transliteration was adopted to render titles of nobility. "Sir" and "Lord" became “沙” and“律” respectively, both of which have nothing to do with a title of nobility in Chinese. The honorary titles were even deleted sometimes. A typical example is the translation of “Captain Elliot”, which became “义律(Yi Lu)"in the target text. The title "Captain” was totally omitted in the translation. Another typical example is the transliteration of "Lord Napier", who was the first British commerce supervisor sent to China. The Chinese version is “律唠啤”.“律” was transliterated from“Lord”, and“劳卑”means laboringand in a low status （刘禾，2009: 64）.Compared with“纳陛”and“无比”translated by Robert Morrison and his son John Robert Morrison, this version was evidently hostile and contemptuous.(Wang Hongzhi, 2013(5):23-27)

Moreover, to cater to the mainstream ideology of the national cultural arroganceand the sense of superiority as a thousand-year-old superpower, translators also distorted the diplomatic relationship with the foreign countries by dwarfing the foreign counties and showingthe superiority of the Qing dynasty.

Example1:(Su Jing, 2015: 952 )

ST: What answer was returned on the 9th, or whether indeed any came or not, we are 
unable to state.

$\mathrm{TT}$ : 于初九日即八月十四日, 未知有批回无批回。即有批回, 又未知如何批语, 我等俱不能知道。

The word “answer" was rendered into “批回”( $P i$ hui, replying message from a subordinate)“批语”(pi yu, replying message from a subordinate), which indicate that Qing dynasty was the superior .

Example2:(Su Jing, 2015:944)

ST: On the 13th, an officer was dispatched by Keshen, to the squadron, with orders to supply the ships with provisions; and cattle, sheep, \&c., were brought off plentifully.

$\mathrm{TT}$ : 于十三日即七月十六日琦派官来到船上，赐牛羊牲口、火食等物。

The word"supply"in the source text means "to provide the British with the provisions they want ". However, in the Chinese translation, it was rendered into the “赐” ( $c i$, to grand a reward, indicating the superiority of the Chinese side.

Example3:(Su Jing,2015:265 )

ST:When Capt. Smith sent a despatch to the Commissioner at Chuenpee the purport of which was a demand that the Commissioner should withdraw his often repeated threats of burning and destroying the English merchant fleet now at Hongkong.

TT: 吐嘧一到穿鼻, 即递禀帖, 求钦差不要烧毁在尖沙嘴湾泊之船只。

In the original text, the British side sent an urgent document to the Chinese side. Such words as "demand" and "should" show that it was a stern and forceful request, indicating condemnation of the threats made by Chinese side. However, in the target text, "despatch" (an official report usually sent in haste) was distorted into “禀帖”(bingtie,official report to the superior), and “demand"(request urgently and forcefully) was translated into “求”(qiu, to beg, to ask for a favor), both of which showing the British was in an inferior position, subordinate and submissive.

\section{Conclusion}

As the patron, Lin was directly involved in various steps in the translation activities of Ao-men Hsin-wen-chih, ranging from selection of translators, selection of source newspapers and the subjects of source texts, to target-text note-adding and choosing other target readers. As the undifferentiated patron, his manipulation determines to a great degree the translation of Ao-men Hsin-wen-chih.Moreover, Lin Tse-hsu's ideology was like an invisible hand from behind controlling the translators' translating strategies.

The translators selected and complied the information to echo Lin's ideology. Foreignization strategy was adopted to keep the original information while at the same time catering to Lin's demand to know about the foreign affairs. Meanwhile, domestication was employed in order to cater to the reading habits and the ideology of the target readers. In addition, intentionally or unintentionally, the translators rewrote the translation to uglify and dwarf the image of the foreigners, and to show the superiority of the "celestial empire".

\section{Notes:}

1. Those annotations are listed on p.440, p.460, p.473, p.512. in Collection of Papers on the Modern China: Opium War Volume 2.

2. Punctuation of this part and of the following translated texts are added by the author. 
3. The year then was designated by imperial calendar (the title of an emperor's reign) with Heavenly Stems and Earthly Branches in China, for example, the first year during the reign of emperor Jiaqing corresponded with Geng in Heavenly Stems and Chen in Earthly Branches.

4 The Chinese character “蛮夷” (man yi) was originally a name used to refer to the ancient tribes. Later, it was used to refer to the foreign country.

\section{Acknowledgement}

This paper is sponsored by the general project---Cross Cultural Communication Study on Translation of Peking Gazette supported by National Philosophy and Social Science Foundation (Project Number: 15BXW005). It's also a result from the research project "Construction of Images of the West: On the Translation of Ao-men Hsin-wen-chih" sponsored by Guangdong University of Foreign Studies.

\section{References}

Association of Chinese Historians. Collection of Papers on the Modern China: Opium War Volume 2. Shanghai: Shenguang Publishing House. 1954.

Britton S. Roswell (1966).The Chinese Periodical Press: 1800-1912 Taipei: Ch'eng-Wen Publishing Company.

Fang Hanqi (1996). The General History of Chinese Journalism. Beijing: Renmin University of China.

Feng Zuyi. Probing into Ao-men Hsin-wen-chih. Guizhou Social Science 2010 (7)

Lefevere, Andre (1992). Translation, Rewriting, and the Manipulation of Literary Fame. London $\&$ New York: Routledge.

Li Changyin. Translation and Historical Context: the semantic evolution of $Y i$ and its English Translation. Journal of YunnnMinzu University 2008 (7) .

Lin Tse-hsu. Letters by Lin Tse-hsu Fu Zhou: FuJian People's Publishing House. 1839/1981

Su Jing (2015). Ao-men Hsin-wen-chih (Macau News): Its History, Original, Translators, and Translation. Shanghai: Fudan University Press.

Tymoczko\&Gentzler.Translation and Power. Amherst: University of Massachusetts Press. 1999

The Canton Register.. 1839-9.1-30, 1839-7-16.

The Canton Press. 1839-10-12, 1840-1-18, 1839-11-9.

The Chinese Repository.1839-9.1-30, 1839-12-26, 1839-10-19, 1839-11-2.

The Chinese Repository.1841-10-565.

Venuti, Lawrence. The Translator's Invisibility A history of Translation. London and New York: Routledge. 1995.

William C. Hunter. Bits of Old China. London: Kegan Paul, \& Co. 1855.

Wang Hai, Chen Caiyun. On the Translation Strategy and Techniques of Ao-men Hsin-wenchihThrough the Lens of Patron Theory. Journal of International Communication. 2013

Wang Hongzhi. The Translators in The First Opium War, 1839-1842, Part One: Translators/Interpreters of the British Camp. Studies in Translation History (2011, Vol. 1) Shanghai: Fudan University Press, 2011.

Wang Hongzhi. Napier and Napeih: Name Translation and Sino-UK Diplomacy Conflict. Chinese Translators Journal. 2013 (5). 